\title{
The Mandate Of Making Disciples: Teaching As Incarnational Ministry
}

\begin{abstract}
This paper discusses how the Church can achieve the goal of discipleship through an "incarnational" model of teaching. It argues that teaching in the Church should be incarnational so as to realize transformation in the lives of people. Incarnation is used in the sense of the word of God which the Christian leader has been commanded to teach, becomes flesh and makes a dwelling among the people so that the learner can behold the glory of the word being lived out in human life. The Pastoral ministry must engage in teaching so that learners can become new creations who demonstrate the nature of Christ. In discipleship, the pastor acts as the teacher of teachers, equipping the laity so that they can teach others. Teaching, a key aspect in Christian education, is at the heart of discipleship. As such, for the teaching ministry to be incarnate, it must identify with Jesus Christ. What is preached and taught must become flesh in the teacher's own life and help the learner to behold the glory of Jesus the Christ.
\end{abstract}

Keywords: Discipleship, Pastoral ministry, Incarnational ministry, Christian education, teaching

\section{JOHN ABEDU QUASHIE ${ }^{1}$}

${ }^{1} J o h n$ Abedu Quashie (PhD) is a Lecturer in Practical and Pastoral Theology, the Dean of Students, and Director for Professional Programmes at Trinity Theological Seminary, Legon, Ghana.

Email: jaquashie@yahoo.com

\section{Manuscript}

Received 27th April 2020, Accepted 2nd June 2020,

Published online 10th June 2020.

\section{INTRODUCTION}

Churches in Ghana have recently become concerned about the obvious lack of discipleship, a situation in which many people call themselves Christians but they cannot be said to be true disciples of Jesus Christ. To deal with the issue, there has been a call in many churches to intensify the teaching ministry of the church. This call, which actually is an emphasis on the mandate given to the church to make disciples, is made with the hope that teaching will help people to understand the principles of the Christian life and to live by those principles. It is not the case that before this time the church has not been teaching. The church has been teaching and yet there has not been the realization of transformation in the lives of people. It seems that the problem has to do with "how" the teaching is carried out. The question then is, how do disciple makers teach to achieve the goal of believers developing the very nature of Jesus Christ? This paper proposes that for the church to achieve the goal of discipleship, that is, helping people live like Jesus Christ, an "incarnational" model of teaching must be adopted. It argues for an approach to teaching in the church that is incarnational, and the teacher or disciple maker who leads the educational process must be an incarnational leader.

\section{Disciple Making and the Mandate to Teach}

The Matthean version of the Great Commission emphasizes the place of teaching in the process of disciple making. It reads, "Therefore go and make disciples of all nations, baptizing them in the name of the Father and of the Son and of the Holy Spirit, and teaching them to obey everything I have commanded you. And surely I am with you always, to the very end of the age" (Matthew 28:19-20 NIV). The International Leadership Institute defines a Christian disciple as, "Someone who is living out the decision to follow Christ in everyday life. He or she is a person who knows Christ 
inwardly and is committed to living outwardly in love and obedience to Him."2 The process of making disciples is referred to as discipleship. It is the "relational process of helping someone grow spiritually from childhood to maturity. It is done by building the principles of God's Word into that person's life so they are equipped to understand and follow the prompting of the Holy Spirit in knowing how to respond to any situation with Christ-like attitudes and actions." 3

Teaching is the means by which the principles of God's Word are built into people's lives. Some commentators have suggested that in Ephesians 4:11ff, the offices of the pastor and teacher are the same office. That is what we see in the contemporary church; the pastor takes the role of the teacher to build the affective, cognitive, psychomotor aspects of members so that the full potential of the individual can be unearthed. Although the pastor is a teacher, the church expects other lay members to perform the role of teaching. This is because the mandate of disciple making applies to all believers. The pastor then acts as the teacher of teachers, equipping the laity so that they could teach others.

Teaching is a process of sharing knowledge with others with an aim of increasing psychological and intellectual growth of an individual. Teaching may be directive or facilitative. In the directive approach, the teacher is regarded as one with knowledge in a particular field and is expected to impart that knowledge to their learners through variety of means. The teacher thus leads a group of students in attaining new abilities, acquaintance, or knowledge. As such, the teacher's expertise is more valuable than students. As facilitators, teachers build on the knowledge base of the group so each contribute to find answers to questions. Schwarz describes a facilitator as a "substantively neutral third party, acceptable to all members of the group, who has no substantive decision-making authority." $\mathrm{A}$ facilitator's purpose is to increase a group's effectiveness by engaging participants in creating, discovering, and applying learning insights so that each brings out some knowledge to build one another.

Teaching and learning go together. Thus, the teaching ministry of the church is an educational endeavour in the sense that it involves teaching and learning. Different educational models and methods have been used. Educational models of making disciples of Christ have been employed by some church leaders. An example is John Wesley, founder of the Methodist Church, who in the Eighteenth Century developed a church that thrives on education, involving the lay. The Class system, Bible Bands and other small groups which lie at the heart of a society was to be an educational forum where members build their knowledge. The function of the Class meeting was focused on behavioral change where the class leader facilitates others to share their experiences for affective change. Ten to Twelve people, including both sexes, met weekly for testimony, "interpersonal dynamics," and "the alteration of behavior." The function of the Band was also affective. It was a smaller group, separated by sex, age, and marital status, aimed at "ruthless honesty and frank openness, in which its members sought to improve their attitudes, emotions, feelings, intentions, and affections." 6 Other groupings including the Select Societies (for training) and the Penitent Bands (for rehabilitation of backsliders) were also platforms to educate learners. Such models of teaching are models of Christian Education.

Education in the church must be holistic. Every human being has a physical, mental, emotional, social and spiritual dimension. The development of all the dimensions of an individual is the function of true Christian education. ${ }^{7}$ Kungumaraj David asserts that, "Christian education is a discipline which helps to mould the mental, physical and spiritual attitude of children and thereby paves a path to their best living as the most promising citizens and Christian leaders of our country." Hence, Christian Education helps the believer to pursue Christlikeness for the sake of social and cultural engagement. Such pursuance of Christlikeness involves a number of things as noted by Gravissimum Educationis thus:

Christian education ... has as its principal purpose this goal: that the baptized, while they are gradually introduced the knowledge of the mystery of salvation, become ever more aware of the gift of Faith they have received, and that they learn in addition how to worship God the Father in spirit and truth (cf. John 4:23) especially in liturgical action, and be conformed in their personal lives according to the new man created in justice and holiness of truth (Eph. 4:22-24); also that they develop into perfect manhood, to the mature measure of the fullness of Christ (cf. Eph. 4:13) and strive for the growth of the Mystical Body; moreover, that aware of their calling, they learn not only how to bear witness to the hope that is in them (cf. Peter 3:15) but also how to help in the Christian formation of the world that takes place when natural powers viewed in the full consideration of man redeemed by Christ contribute to the good of the whole

2 International Leadership Institute, National Conference: Eight Core Values for Christian Leadership (Carrolton: International Leadership Institute, 2015), 113

Ibid., 113

4 Roger Schwarz, "Using facilitative skills in different roles," in The Skilled Facilitator Field Book: Tips, Tools, and Tested Methods for Consultants, Facilitators, Managers, Trainers, and Coaches, eds., Roger Schwarz, Sue McKinney, Peg Carlson \& Anne Davidson (San Francisco: Jossey-Bass, 2005), 27.

D. M. Henderson, Model for Making Disciples: John Wesley's Class Meeting (Nappanee, IN: Francis Asbury Press, 1997$), 96$.

Ibid., 112.

Vimala Paulus, Introducing Christian Education (Bangalore: The Church of South India for Child Care, 1993$), 1$.

Kungumaraj David, "Christian Education in the Context of Secular Education" in India in Looking Ahead in Christian Education edited by Lal Rinmawia (Delhi: ISPCK, 1984), 43. 
society. ${ }^{9}$

Christian education thus leads, not only to the transformation of the person, but also the transformation of the church and of the society at large. In many respects, Christian education is discipleship, because as the teacher builds the learner, the learner grows into maturity to build other people. Hence, the pastor, as a teacher, has a key role in the all-round development of the individual stressing how they may develop in ways patterned on the life of Jesus Christ and live in obedience to the Lordship of Jesus Christ. ${ }^{10}$ The prime focus is to present each person mature in Christ $(\mathrm{Col}$ 1:28-29). Discipleship achieves its goal when the learner can begin to disciple others. ${ }^{11}$ The teacher accomplishes their task when the learner embodies their own teaching in their life and begin to serve as teachers by contextualizing what has been learnt with new insights and new approaches. ${ }^{12}$ In essence discipleship is Christian education. Furthermore, Christianity without Christ-like living is nothing. Bonhoeffer explains that:

Christianity without the living Christ is inevitably Christianity without discipleship, and Christianity without discipleship is always Christianity without Christ. It remains an abstract idea, a myth which has a place for the Fatherhood of God, but omits Christ as the living Son. And a Christianity of that kind is nothing more or less than the end of discipleship. ${ }^{13}$

Bonhoeffer further avers that Christians are called to a life of radical discipleship in Christ. It is radical because the disciple is called to a life of devotion to the Word of God. The teacher of the word or the disciple does not come up with his or her own words or concepts but focuses on the Word of God. When left to our own ideas and reasoning, we cannot engage in true theology; we can only engage in mythology because our thoughts and language are inadequate and distorted. ${ }^{14}$ People have a tendency to "construct" their own understanding of the biblical truth, but the Christian never compromises the firm conviction that truth is in Christ, established and known by God through incarnation. The Christian epistemology encompasses the whole range of knowledge: factual, conceptual, procedural and metacognitive. ${ }^{15}$ Chambers explained, "We have not to study and understand ourselves; but to understand the manifestation in us of the life of the Son of God." 16

Again Bonhoeffer advocates that, the disciple is called to a life of radical obedience empowered by the grace of God. Grace and obedience always go together: "only he who believes is obedient, and only he who is obedient believes." 17 The one who seeks to be a disciple must desire for an understanding heart in order to walk in the ways of God. As Proverbs 14:6 puts it, "Knowledge is easy to him who understands. (NKJV)" The long-established truths of the Bible must be taught in a dynamic way and interpreted so that the learner does not only hear the truth as abstract but as practical life.

Disciple making involves a teaching ministry by committed persons who have encountered Christ. It is not a vocation for volunteers, for the hired labourer will feed on the sheep rather than feeding the sheep (Ezekiel 34:1-6). The attempt to pick anyone to teach in the church could disrupt the teaching ministry and lead to poor results. It must be engaged in by persons who themselves are committed to becoming true disciples of Christ.

It is not only the learner who ought to live out in practical life what is learnt but more importantly the teacher. As long as the teacher's life is consistent with what they teach the learner can identify with it. It is then that what they teach becomes "flesh," that is, it becomes practical in the life of the teacher and that makes it possible for the learner to see with the eyes, touch with the hands and feel in the heart and bear witness. The teacher engaged in Christian education belongs to sacred leadership because such a person is called by God. The sacred leadership faces the challenge of communicating God's vision to the followers convincingly through the life of the leader. It is leadership by example and not the usual parlance "do not look at what I do but what I say."

\section{The Biblical Basis of Teaching in Discipleship}

A disciple may be referred to as a person who is learning from the master to become just like the master. From the

\footnotetext{
9 Gravisimum Educationis, Declaration on Christian Education, Proclaimed by his Holiness Pope Paul VI on October 28, 1965, http://www.vatican.va/archive/hist_councils/ii_vatican_council/documents/vat-ii_decl_19651028_gravissimum-educationis_en.html, accessed May 28, 2020

10 Paulus, Introducing Christian Education, 2.

11 James R. Estep and Jonathan H. Kim, Christian Formation: Integrating Theology \& Human Development (Nashville, Tennessee; B\&H Academy 2010), 93.

12 John Milton Gregory, The Seven Laws of Teaching (Veritas Press, 2004), 141.

13 Dietrich Bonhoeffer, The Cost of Discipleship. A Touchstone Book (New York: Simon and Schuster, 1995), 59.

14 Dietrich Bonhoeffer, Life Together (New York: HarperOne, 2009), 84,85.

15 L. Anderson, D. Krathwohl, P. Airasian, K. Cruikshank, R. Mayer, P. Pintrich (eds.), Taxonomy for Learning, Teaching, and Assessing: A Revision of Bloom's Taxonomy of Educational Objectives (New York: Longman. 2001), 38-62.

16 O. Chambers, "Psychology of Redemption," in Complete Works of Oswald Chambers, eds., B. Chambers \& D. Lambert (Grand Rapids, MI: Discovery House, 2000), 1061.

17 Bonhoeffer, Cost of Discipleship, 63.
} 
Christian perspective, a disciple of Jesus is someone who is learning from the life of Jesus Christ in order that they may become just like Jesus. Bill Hull argues that the concept of discipleship came out of the rabbinical schools. He argues thus, "Every Jewish boy by age thirteen had studied and memorized much of the Pentateuch and the prophets. If he was among the best and the brightest, he would be accepted into a rabbinical school. There he will study under the authority of his teacher." ${ }^{18}$ There were five characteristics of the rabbinical school: (1) The disciple chose to submit to his teacher; (2) The disciple would memorize his teacher's words; (3) The disciple would learn his teacher's way of ministry; (4) The disciple would imitate his teacher's life; and (5) The disciple would be expected to find his own disciples. ${ }^{19}$

Even though the concept of discipleship in Christianity comes from the rabbinical school, Jesus' idea of discipleship was different from that of the rabbinical school. He had warned the disciples that they were not to be called Rabbi or teacher, because there was only one teacher, the Christ (Matthew 23:1-10). By this he meant that unlike the rabbinical schools in which the rabbi's life becomes the pattern to be imitated, none of his followers' life was to be a pattern for imitation. If there is only one teacher, Jesus the Christ, then he alone becomes the focus and his life alone becomes the pattern for imitation. To Hull, adopting the five characteristics of a first century disciple, as modified by Jesus, is the secret to personal transformation that will lead to church transformation that will result in cultural transformation..$^{20}$ The modified characteristics are: (1) A disciple submits to a leader who teaches him to follow Jesus; (2) A disciple learns Jesus' words (3) A disciple learns Jesus' way of doing ministry (4) A disciple imitates Jesus' life and character; and (5) A disciple finds and teaches disciples to follow Jesus. ${ }^{21}$

The difference between Christian discipleship and the Rabbinical school therefore is that whereas in the rabbinical school the focus is on the Rabbi, in Christian discipleship the focus is on Jesus Christ. The Christian disciple not only learns Jesus' words and way of ministry, but also imitates the life and character of Jesus. Thus if one is being discipled, that person gradually grows into Christlikeness and begins to live the life of Jesus Christ.

Paul indicated in Colossians 1:28 that the means by which he could help present people as perfect (Greek: teleion) in Christ Jesus was through teaching. This is in consonance with Jesus' own command in the Great Commission where the authority is given to teach people to obey everything that Jesus had commanded (Matthew 28: 18-20). There are three important actions called for by the Matthean text. These are: going, baptizing and teaching. Going (Greek: poreutentes) is an aorist passive participle that could be understood to mean, "as you are going." According to Bill Hull, the command of the text is not to go. ${ }^{22}$ While going is circumstantial, baptizing and teaching qualify the main commanded action of the text. Baptizing converts require that believers make a public profession of faith. Teaching others to obey is the most important ongoing ingredient for a meaningful Christian life. ${ }^{23}$

Paul puts the idea of discipling people to become like Jesus Christ in these words in Colossians 1:28-29, "We proclaim him, admonishing and teaching everyone with all wisdom, so that we may present everyone perfect in Christ. To this end I labor, struggling with all his energy, which so powerfully works in me. (NIV)" The Greek word Paul uses which is translated 'perfect' or 'mature' is Teleios. Three meanings come out of the Bible's use of this word. These are, conformity to the highest standard; maturity to the fullest degree; and ethical completeness. ${ }^{24}$ Persons attain teleios through the activity of teaching.

The critical role of teaching in the work of the church as she seeks to fulfill the great commission has well been noted. Donald Griggs emphasizes that, "Teaching is not just one of the ministries of the church; it is a high priority of the church's life and work." ${ }^{25} \mathrm{He}$ argues that even though worship, evangelism, and social action are all important aspects of Christian ministry, without teaching these are not done well. Without teaching, "worship may become mostly a habitual religious ritual. Without teaching ... evangelism may become shallow or just a marketing of the church. Without teaching ... our service may become just good works." ${ }^{26}$ Karen B. Tye also quotes Thomas Groome thus, "I will avoid saying that education is the most important ministry in the Christian community. But I do claim that it is second to none." ${ }^{27}$ Such statements have not been made out of the blue. They are based on biblical facts. It is therefore necessary to point out the facts from the Bible regarding the place of teaching in Christian ministry.

The apostles sent by Jesus were committed to teaching. They began to preach the great truths about Jesus Christ by showing their distinctively Jewish congregation how the Old Testament prophets showed he was the Messiah. They

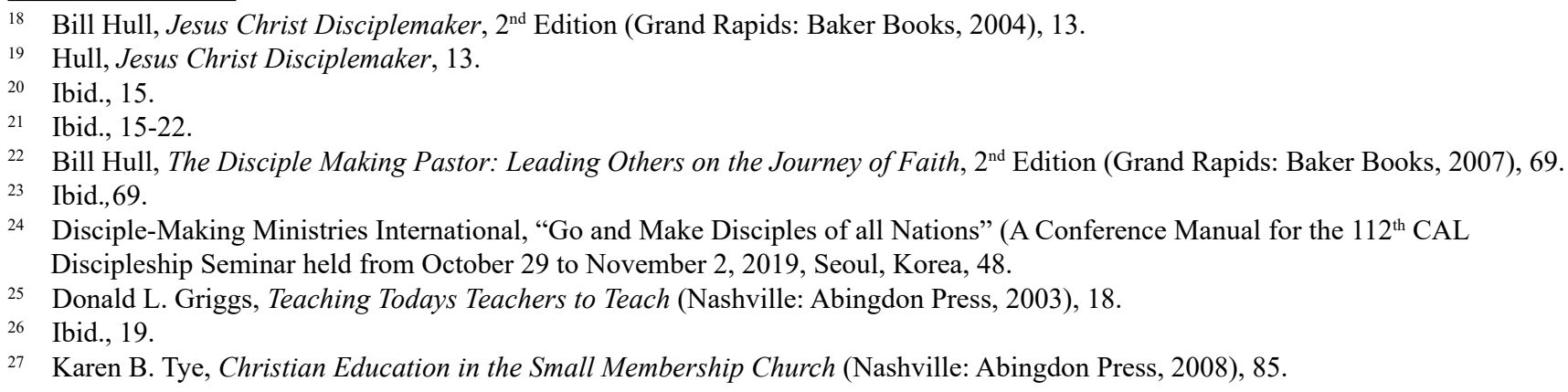


provided Jesus' teaching on life, death, and the eternal state. Throughout the book of Acts of the Apostles, we discern that the apostles were engaged in a consistent and systematic teaching ministry.

The book of the Acts of the Apostles helps us to appreciate how the apostles took the command of Jesus to "teach them" seriously. The syntax of Acts 2:42 gives a sense of teaching that was consistent and intentional. It explicitly uses the active participle to give an impression of steadfastness and perseverance. Effective formation and development of community through teaching must be a continuous activity with some consistency. In the Jerusalem church, the apostles' prioritized teaching; they made the believers intensely devote themselves to teaching; it became a way of life (Acts 6:4). This means that true spiritual formation requires such commitment to consistency of practice and that the first priority that the apostles were committed to was a commitment to the scriptures. ${ }^{28}$

The teaching ministry did not end with the disciples who gathered in the Upper room. The story of Philip and the Ethiopian Eunuch who was travelling on the road between Jerusalem and Gaza, found in Acts 8: 26-40 also underscores the importance of teaching. The Eunuch was reading the prophet Isaiah and Philip asked him if he understood what he was reading. According to Tye, the answer of the Eunuch, "How can I, unless someone guides me" (vs 31) underscores the vital necessity for education in the church. If people are to understand and apply biblical principles to every situation they meet in life, they need to be taught. It is for this reason that the early apostles made teaching a priority in their ministry. ${ }^{29}$

The writer of Acts also refers to the teaching ministry of Barnabas and Saul: "So for a whole year Barnabas and Saul met with the church and taught great numbers of people. The disciples were called Christians first at Antioch" (Acts 11: 25-26 NIV). Barnabas and Saul did not teach alone. They had others to help in teaching at Antioch: "But Paul and Barnabas remained in Antioch, where they and many others taught and preached the word of the Lord" (Acts 15:35 NIV). The believers were called Christians in Antioch because having been taught they began to live like Jesus Christ.

Furthermore, Acts 19: 8-10 helps one to appreciate the length to which the apostles would go in their effort at teaching the people. Paul spoke boldly there for three months, arguing persuasively about the kingdom of God. When Paul left those who refused to believe, "He took the disciples with him and had discussions daily in the lecture hall of Tyrannus. This went on for two years, so that all the Jews and Greeks who lived in the province of Asia heard the word of the Lord" (Acts 19:9-10 NIV). From all of these scriptures, one can recognize the apostles giving priority to teaching and making all the effort, even in the midst of opposition, to ensure the disciples were taught. We also recognize the consistency with which they engaged in this important task of teaching.

For Paul, the reason for which in the church some were made apostles, prophets, evangelists, pastors and teachers is to equip the saints until they attain the "the whole measure of the fullness of Christ" (Ephesians 4:11-13 NIV). We can say that this has to do with nurturing the saints until they become mature and live like Jesus Christ. Teaching must be done in a spirit of profound common sense so that we can bring each person to maturity. To be mature is to be basic. This then is the goal of discipleship. The perfect or mature disciple integrates in their faith and life obedience to God in the areas of their mind, heart, will, relationships and actions after learning who Jesus is. And that is God's plan and purpose for all members of His body, that they attain the whole measure of the fullness of Christ (Ephesians 4:13). The question then is, what did the apostles teach to make the believers become like Jesus? What should be the content of one's teaching?

\section{The Content of Teaching}

What is the content/ curriculum for discipleship? What is a teacher going to disseminate regarding discipleship? In Matthew 28: 18-20, Jesus commanded his disciples to teach those who believed and are baptised to obey everything He had commanded. This passage suggests what has to be the content of teaching; everything Jesus had commanded. But what had Jesus commanded them? It seems to this Author that what Jesus had commanded them, which has to be taught as one seeks to make disciples, has to do with "Scripture". Jesus had earlier told them that he had not come to abolish the law but to fulfill them (Matthew 5:17) and in his conversation with the men he met on the road to Emmaus, it is told in Luke 24:27 that, "Beginning with Moses and all the Prophets, he explained to them what was said in all the Scriptures concerning himself" (NIV). So, what Jesus taught or commanded has to do with what the law and the prophets have said about him. It could be for this reason that on the Sabbath at Pisidian Antioch, after the reading from the law and the Prophets, when Paul and Barnabas were requested by the synagogue rulers to speak, Paul referred to incidents in the law and the prophets as pointing to Jesus, and ended his message with the fact that the raising of Jesus was what God had promised their forefathers (Acts 13:16-33). Later, Paul would admonish his son in the faith, Timothy, in 2 Tim 3:16 that, "All Scripture is God-breathed and is useful for teaching, rebuking, correcting and training in righteousness" (NIV). And the scriptures point to Christ Jesus.

Also, in Colossians 1:26-28, Paul talks about the mystery, that is, "Christ in you the hope of Glory." It is this

28 Hull, The Disciple-Making Church, 68.

29 Tye, Christian Education, 85. 
mystery which is the substance of discipleship or the curriculum for discipleship. Any message that does not emphasize Christ Jesus cannot help people become like him. And so, the curriculum, or what has to be taught is as Paul puts it in Col 1:28, "We preach Christ" (The Message). It is the preaching and teaching of Christ Jesus which makes the gospel an offence. The only fight the Sanhedrin had to fight against the early apostles was that they were preaching Christ Jesus. In Samaria, Philip preached Jesus and he began from the scripture. Christ is the inexhaustible subject that must be taught, no more, no less. He is the content of teaching persons to be disciples. If teachers have not preached and taught Christ Jesus, then they have not preached and taught.

What is involved in teaching Christ Jesus? It involves at least three things; teaching what the Scriptures say about him and how they point to him; teaching what he taught: and teaching how he lived. When these are taught, learners come to understand the nature of the Christlike life they are expected to live and how such Christlike life should affect every aspect of their interactions leading to the transformation of the church and the society. It is for this reason that teaching should focus on Christ. Teaching these would make clear the transformation expected in the lives of persons, the church and the society as a whole. Bryan Chapell avers that:

God fully reveals the dynamic power of his Word in the New Testament where he identifies his Son as the divine logos, or Word (John 1:1). By identifying Jesus in his Word, God indicates that his message and his person are inseparable. The Word embodies him. This is not to say that the letters and the paper of the Bible are divine but that the truths Scripture holds are God's means of making his person and his presence real to his people. ${ }^{30}$

Christ is the content of teaching because in him dwells the fullness of the Godhead (Colossians 1:19) and he is inseparable from God's message to humankind as Chapell notes. Teaching Christ is therefore teaching God's message to humans.

\section{Teaching as Incarnational Ministry}

The critical call of this paper has to do with how to teach for the goals of discipleship to be realised. The teaching ministry in the Church has often focused on information. Learners may be made to learn by rote, sometimes without understanding what they are being taught. Even when what is taught is well explained to them, it may be taught in such a way that learners gain some information about the issue at stake but they are not helped to apply that knowledge to their lives. Whereas learning experiences are supposed to lead to change in behaviour, such approach does not help learners to experience any change in their lives. Furthermore, the teacher's life may be contrary to what they teach. For example, a teacher may explain from the Bible to learners that extra marital affair is sin, but the teacher may be involved in an extra marital affair. Such teaching does not lead to the required transformation anticipated in disciple making.

This paper therefore suggests an incarnational model of teaching as a means of achieving the goals of discipleship. Incarnation has always been an important concept within Christian theology. For centuries theologians have wrestled with how best to conceptualize the vexing problem of what it means that Jesus the Christ is fully God and fully human. The term "incarnation" was built upon the word "flesh", to capture the concept of Jesus becoming flesh (Jn. 1:14) [

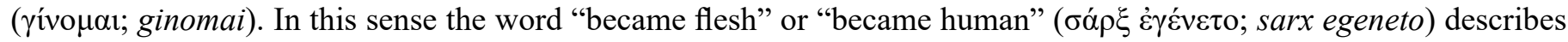
the process of embodiment or to become "enfleshed." The English noun "incarnation" derives from an old French word incarnatio which is from the Latin incarnatus which is the past participle of the verb 'to incarnate' pointing to the idea of to "enflesh", "take flesh", or "clothe with flesh". Thus, the modern verb (incarnate) and noun (incarnation) describe the unique action of God to enflesh Jesus Christ into our world. Andrew Root argues that incarnation can be understood as a verb, a word that speaks of an action, and in this case the action of a person." ${ }^{31}$ Darrel Guder also opines that:

To speak of the incarnation is always to speak of Jesus Christ, the Lord, the once-for-all event of God's

saving work in the world and for the world.... It is a noun that summarizes the 'what' of the gospel, rooted

in the 'why' of God's compassion for creation and purpose to bring about its salvation. At the same time,

it is a concept that, in a very profound way, defines the 'how' of gospel witness. There is a fundamental

pattern to God's self-disclosure throughout all the scriptures. ${ }^{32}$

In Philippians 2:5-7, Paul describes the incarnation of Christ as emptying himself to take human flesh. The key word in

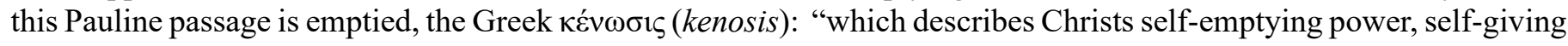
love and radical servanthood, revealed in the Word become flesh... kenosis expresses God's glory...God's self-giving, cruciform love, kenotic love." ${ }^{33}$ Gregory of Nyssa said of this passage: "The Godhead is emptied so that the human nature may accommodate it. What is human, on the other hand, is made new, becoming divine through mingling with the divine." ${ }^{\prime 34}$ Kenosis is such as not being full of ourselves, emptied of ego, void of willfulness, bankrupt of selfishness.

30 Bryan Chapell, Christ-Centred Preaching:Redeeming the Expository Sermon, 2nd Ed, (Grand Rapids: Baker Academics, 2005$)$, 27

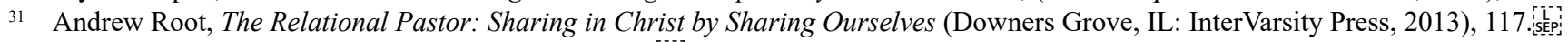

32 Guder, The Incarnation and The Church's Witness, 3.'SËP']

33 Bradley Jersak, A More Christlike God: A More Beautiful Gospel (Pasadena: CWR Press, 2015$), 99$.

34 Thomas Oden and Mark J. Edwards, (eds.), Galatians, Ephesians, Philippians, New Testament Volume viii, Ancient Christian Commentary on Scripture (Grand Rapids: InterVarsity Press, 2005). 244. 
Walking humbly, generous, and effusive in love, as Paul encourages Jesus' followers to imitate Christ by being kenotic in all our relationships. Emptying ourselves of self-will and self-rule to make space for the other. ${ }^{35}$

It was at the Council of Chalcedon that the concept of incarnation was strongly firmed. According to Chalcedon, for any model of the incarnation to be considered theologically legitimate, it must affirm that the human Jesus is the same undivided person as God the Son. Their identity is the same. To qualify as a human incarnate, Jesus must have had both a human soul and body. Jesus must have been human in every aspect, except for him being sinless. This means that for the teaching ministry to be incarnate, it must identify with Jesus Christ. The lesson being taught must have a contextual soul, a body and be without fault. "A Chalcedonian theology of the continuing body of Christ as simultaneously expressive both of his true humanity (local or particular) and of his true divinity (cosmic or universal) offers the possibility of understanding the Church as the community of those who share the discovery that the structure of the world is changed through Incarnation." ${ }^{36}$

Christianity is baseless without Christ becoming flesh. Incarnation cannot merely be an optional quality of ministry, as if there could be any ministry that stands apart from the incarnation of Jesus Christ. Guder believes that the adjectival term "incarnational" which has now become popular was a twentieth century invention. ${ }^{37}$ Worldwide mission work has also employed the concept of incarnational ministry. The Stuttgart Consultation of the World Council of Churches declared in 1987 that "We live by the gospel of the incarnate Lord; this implies that the gospel has to become incarnated in ourselves, the "evangelists." ${ }^{38}$ Charles H. Kraft puts it this way,

He thus became a real human being among us - a learner, a sharer, a participant in the affairs of humans - no longer simply God above us. Nor did he then merely content to do Godlike things near us. He spent approximately thirty-three years truly among us - learning, sharing, participating, suffering, seen, heard, touched; living as a human being among human beings and perceived by those around him as a human being. ${ }^{39}$

The Christian leader seeking to be like Christ, and to teach others also to be like Christ, must symbolize the incarnation of Christ, become flesh to those who are under their tutelage., that is, they must bring their life, which is Christlike, to bear on their teaching.

The basic passage that deals with the concept of incarnation is John 1:14, "The Word became flesh and made his dwelling among us. We have seen his glory, the glory of the One and Only, who came from the Father, full of grace and truth" (NIV). In this passage, the Word is used in reference to the Son of God, Jesus the Christ. Jesus, the Word became flesh and dwelt among humans and offered the opportunity for humanity to behold His glory. 1 John 1:1 puts the same idea this way, "That which was from the beginning, which we have heard, which we have seen with our eyes, which we have looked at and our hands have touched - this we proclaim concerning the Word of life" (NIV). Jesus became flesh so that people would have the opportunity to hear Him as He taught; but they did not only hear what He taught through his spoken words, they also had the opportunity to see what He taught through his life lived among them; they had the opportunity to look at him and observe Him closely, and they had the opportunity to touch Him as a real human person.

The idea of teaching as incarnational is not used in the sense of Jesus, the Word, coming in human form. It is used in the sense of the Christian leader living out in practical life what they teach as they mingle among the people they teach so that the people can see the reality of what is taught being lived out in practical human life. Thus an incarnational model of teaching has to do with the word of God 'being taught', becoming flesh in the lives of the teachers as they dwell among the people they are discipling, so that the people would not only hear the word of God, but also see the word lived out in everyday life and have the opportunity to look at or observe closely. That is the only way the people will behold the glory of the life that has been transformed by the word. The teacher lives the word not only in formal settings but in informal ones as well. Donald Griggs has stated that, "Much - perhaps, most - of what persons learn about the Bible and the Christian faith happens in informal, unstructured, unintentional settings where persons are relating to one another in the context of congregational life and ministry." ${ }^{0} \mathrm{He}$ adds that the "most important and effective teaching in a church will happen when the formal and informal, structured and unstructured, teaching and learning are complementary, when there is congruence between the intentional and the serendipitous learning experiences." ${ }^{\prime 4}$

The incarnational teaching model is a process that involves three salient steps, 1) the exposition of the Word of God, 2) the Word becoming flesh and 3) the Word dwelling among the people. The author uses the life and ministry of Jesus Christ to explain the process. The first step in the process has to do with exposing the Word. This may be done in

\footnotetext{
Jersak, A More Christlike God, 100-101.

36 Oliver Davies, Paul D. Janz, Clemens Sedmak, Transformation Theology: Church in the World (London: T\&T Clark International, 2007$), 55$.

Darrell L. Guder, “Incarnation and the Church's Evangelistic Mission,” International Review of Mission 83.330 (July 1994 ): 417

Quoted by James A. Scherer and Stephen B. Bevans, eds., New Directions in Mission and Evangelization Volume 1: Basic Statements 1974-1991 (Maryknoll, NY: Orbis, 1992), 66.

39 Charles H. Kraft, Christianity in Culture: A Study in Dynamic Biblical Theologizing in Cross-Cultural Perspective (Maryknoll: Orbis Books, 1981), 174

40 Griggs, Teaching the Teacher, 13.

$41 \quad$ Ibid., 13.
} 
a directive manner through proclamation or in a facilitative manner through discussions. In Jesus' life and ministry, he proclaimed the Word directly. The sermon on the Mount, found in Matthew 5-7, is such a directive approach to exposing the word. He also exposed the Word through the facilitative means, especially through the use of parables. This, he did, especially when individuals and groups came to him with life's issues. Instead of offering direct answers, he will use a parable to help the people come to the understanding of the truth.

The second step of the process is derived from the phrase, "And the word become flesh". For effective discipleship, what is preached and taught must become flesh in the teacher's own life. The critical demand in relation to teaching for discipleship is one's own life. The teacher's life must be consistent with what they teach. Once their life contradicts their preaching and teaching and even their writing, their teaching, preaching and writing become useless. If what they preach and teach do not become flesh in their lives, they would have only become talkative and hypocrites. Jesus exemplified this idea in his own teaching when he taught his disciples how to pray (Luke 11:1-2). Before Jesus taught the disciples how to pray, he exemplified the concept of prayer in his own life. Jesus would not have taught the disciples to pray if he did not pray. He taught the disciples to do what they had seen him do. According to AsamoahGyadu:

The disciples saw him praying. When he was done, the disciples wanted to know how to do it [please note that the request does not have the word "how" in it]; the request was this: "teach us to pray".

Literally this means, we want to pray, teach us to do it. This request is therefore not about the

"techniques" of prayer, rather, it is about the "act of praying."

Discipleship is not about techniques. It is about living out a certain kind of life. Living such a life cannot be taught through the verbal teaching of techniques but through the disciple seeing the life lived by the teacher. The word the teacher teaches must become flesh; it must be lived practically by the teacher.

Unless Christ's life becomes lived out in the life of the teacher, the teacher will not be able to do much because their life will contradict what they teach. There is no other alternative. It is only life that begets life. If a woman pregnant for eight months dies, the baby dies too. Only the living produces the living. A dead pastor/teacher cannot produce living disciples. If the church is living and a dead pastor is brought to them, he will kill the church.

The third step in the incarnational teaching model is taken from the phrase, "It dwelt among us"; that is, the word became flesh and dwelt among mankind. Dwelling among people offers the opportunity for visibility. Jesus made it possible for people to see the kind of life he was talking about. In John 13: 3ff, He washed the feet of his disciples and asked them to do same. Those who take up the task to disciple others, teaching them to live like Christ, need to dwell among them for them to see them as they are. When those who disciple others give them the opportunity to see their lives, they remember what to do. The best way to teach people about service, for example, is that the people see you serving. In Jesus life and ministry, it was when the disciples saw Him serving by washing their feet that they understood that leadership was not about taking up positions but about serving.

The idea connoted by the word dwelt is different from the idea of visit. A visit is temporal while dwelling is a permanent continuous action. When one visits, one does not see much of the visitor but when the person comes to dwell, it is possible to see everything about that person. In the First letter of John, the writer did not only talk about what they had seen with their eyes, but also what they had experienced (1 Jn 1:1). When one dwells, people do not only see them in passing but they are able to look at them closely and observe clearly. Jesus was not a masquerade to the disciples. They observed him sleep; they observed him hungry; they observed him tired; they observed him eat; they observed him weep; they observed him pray; they observed him heal and they observed him do many other things. The incarnational teaching model means that teaching must move from just talking to becoming flesh. That is, walking the talk; to dwelling among those being discipled so that they would observe how the teacher responds in Christ-like manner to every situation of life.

The intriguing outcome of such a process of the incarnational teaching model is that, it helps the learner to behold the glory of Jesus the Christ through those who follow Him. To behold is to look intently. One does not see something in passing. That thing is not an apparition. People can see things by chance. To behold on the other hand is to look at intentionally. The church must give opportunity for people to behold the glory of Christ being displayed in the life of the teacher as they check out the teacher of the gospel. Staying with an individual for two weeks in his/her house will make the host intentionally see who the visitor is exactly. That host will learn how to live the life that the visitor has been living. When the teacher dwells with the learners, the learners behold the teacher and see how he or she lives, whether the life is of grace, truth and glory.

Incarnational model of teaching encourages the teacher to be social, bringing him/her into community with the body of Christ, fostering healthy human relationships, to bear each other's burdens. Christian teachers who adhere to

\footnotetext{
42 J. Kwabena Asamoah-Gyadu, "Disciple Making in the Methodist Church Ghana: Prospects and Challenges" (Unpublished paper presented at the School of Continuing Education of the Methodist Church Ghana on July 3, 2019 at the Freeman Centre for Missions and Leadership Development, Kumasi)
} 
incarnational model dwell among the disciples, living out the life of Christ so as to transform the disciples as Jesus did.

For the ministry of teaching to be incarnational, it must meet people where they are, bringing them the message of truth which will transform their mind, heart and being, not only to become a spiritual person but also a physical being able to relate with the world and other people. The incarnational model of teaching imparts Christ's nature and culture in one's own cultural context. An incarnational ministry is both spiritual and physical. The change is not accomplished by oneself but by a moral revolution through which Christ is formed in His disciples.

Pastoral ministry must engage in teaching that helps learners to grow into the likeness of Jesus Christ. The very nature of the Incarnation, God becoming human, was in itself enough to start the salvation process. "God had become human and thereby shown that human nature could carry the divine glory; God had raised the whole of human nature and therefore every man and woman to new dignity, by opening to all a share in the fellowship of Christ's body." ${ }^{43}$ God becoming human re-consecrated the material order in a way that inaugurated the new creation. It was not about destroying the old creation to be in a purely spiritual realm but for the full created universe of heaven and earth to be fully united for "grace does not destroy nature but brings it to perfection." ${ }^{44}$

\section{CONCLUSION}

Christians have been commanded to make disciples of all nations. As they preach about Jesus Christ, those who believe are to be baptized. Having done that, the mandate to teach remains the critical ongoing ingredient in the Church's ministry Teaching must focus on Jesus Christ and is intended to help believers grow into the very likeness of Jesus Christ leading to the transformation of the church and society. The early disciples prioritized the mandate to teach. When Paul and Barnabas had taught the believers in Antioch, they began to live the Christ-like life to the effect that they were called Christians. Even though teaching goes on in the contemporary Christian milieu in Ghana, the Christlike life that is aimed at seems not to be achieved. This paper has pointed out that the manner of teaching, which often focuses on information, and in which the teacher's life sometimes contradicts their message account for the lack of transformation. It has been proposed that the incarnational model of teaching, based on John 1:14 and 1 John 1:1, will lead believers being taught to develop the nature of Christ or the attainment of the Christ-like life, which is the goal of discipleship. In this manner of teaching the word of God 'being taught', becomes flesh in the lives of the teachers as they dwell among the people they are discipling, so that the people not only hear the word of God, but also see the word lived out in everyday life and have the opportunity to look at or observe closely and even touch. When the teaching of the church becomes incarnational, it is assured to present everyone perfect (telios) in Christ Jesus.

\section{BIBLIOGRAPHY}

Anderson, L., D. Krathwohl, P. Airasian, K. Cruikshank, R. Mayer, P. Pintrich. Editors. Taxonomy for Learning, Teaching, and Assessing: A Revision of Bloom's Taxonomy of Educational Objectives. New York: Longman. 2001.

Asamoah-Gyadu, J. Kwabena. "Disciple Making in the Methodist Church Ghana: Prospects and Challenges." Unpublished paper presented at the School of Continuing Education of the Methodist Church Ghana on July 3, 2019 at the Freeman Centre for Missions and Leadership Development, Kumasi.

Bonhoeffer, Dietrich. The Cost of Discipleship. A Touchstone Book. New York: Simon and Schuster, 1995. . Life Together. New York: HarperOne, 2009.

Chambers, O. "Psychology of Redemption." In Complete Works of Oswald Chambers. Edited by B. Chambers \& D. Lambert. Grand Rapids, MI: Discovery House, 2000.

Chapell, Bryan, Christ-Centred Preaching:Redeeming the Expository Sermon, 2nd Ed, Grand Rapids: Baker Academics, 2005.

David, Kungumaraj. "Christian Education in the Context of Secular Education." In India in Looking Ahead in Christian Education. Edited by Lalrinmawia. Delhi: ISPCK, 1984.

Davies, Oliver, Paul D. Janz, Clemens Sedmak. Transformation Theology: Church in the World. London: T\&T Clark International, 2007.

Disciple-Making Ministries International, "Go and Make Disciples of all Nations" (A Conference Manual for the $112^{\text {th }}$ CAL Discipleship Seminar held from October 29 to November 2, 2019, Seoul, Korea.

Estep, James R. and Jonathan H. Kim. Christian Formation: Integrating Theology \& Human Development. Nashville, Tennessee; B\&H Academy 2010.

Gregory, John Milton. The Seven Laws of Teaching. Veritas Press, 2004.

43 Rowan Williams, On Christian Theology (London: Blackwell Publishing 2000), 225.

44 Rowan Williams, The Wound of Knowledge (London: Darton, Longman and Todd Ltd, 1990), 131. 
Griggs, Donald L. Teaching Todays Teachers to Teach. Nashville: Abingdon Press, 2003.

Guder, Darrell L. "Incarnation and the Church's Evangelistic Mission." International Review of Mission 83. 330 (July 1994): 417-428.

Henderson, D. M. Model for Making Disciples: John Wesley's Class Meeting. Nappanee, IN: Francis Asbury Press, 1997.

Hull, Bill. Jesus Christ Disciplemaker, $2^{\text {nd }}$ Edition. Grand Rapids: Baker Books, 2004. . The Disciple Making Pastor: Leading Others on the Journey of Faith, $2^{\text {nd }}$ Edition. Grand Rapids: Baker Books, 2007.

International Leadership Institute, National Conference: Eight Core Values for Christian Leadership, Carrolton: International Leadership Institute, 2015.

Jersak, Bradley. A More Christlike God: A More Beautiful Gospel. Pasadena: CWR Press, 2015.

Kraft, Charles H., Christianity in Culture: A Study in Dynamic Biblical Theologizing in Cross-Cultural Perspective, Maryknoll: Orbis Books, 1981,

Oden, Thomas, and Mark J. Edwards. Editors. Galatians, Ephesians, Philippians, New Testament Volume viii. Ancient Christian commentary on Scripture. Grand Rapids: InterVarsity Press, 2005.

Paulus, Vimala. Introducing Christian Education. Bangalore: The Church of South India for Child Care, 1993. Root, Andrew. The Relational Pastor: Sharing in Christ by Sharing Ourselves. Downers Grove, IL: InterVarsity Press, 2013

Schwarz, R. "Using facilitative skills in different roles." In The Skilled Facilitator Field Book: Tips, Tools, and Tested Methods for Consultants, Facilitators, Managers, Trainers, and Coaches, Edited by R. Schwarz \& A. Davidson. San Francisco: Jossey-Bass, 2005.

Scherer James A. and Stephen B. Bevans. Editors. New Directions in Mission and Evangelization Volume 1: Basic Statements 1974-1991. Maryknoll, NY: Orbis, 1992.

Tye, Karen B. Christian Education in the Small Membership Church. Nashville: Abingdon Press, 2008.

Williams, Rowan. On Christian Theology. London: Blackwell Publishing 2000. The Wound of Knowledge. London: Darton, Longman and Todd Ltd, 1990. 